\title{
CUSTOMER GAME EXPERIENCE IMPACT ON GAMIFICATION AND ONLINE PURCHASING
}

\author{
Fortesa HAZIRI(1) ${ }^{*}$, Lulzim SHABANI (1) ${ }^{2}$, Miloslava CHOVANCOVA (iD \\ ${ }^{1}$ Department of Management and Marketing, Faculty of Management and Economics, \\ Tomas Bata University in Zlin, Street Mostni 5139, 760 01, Zlin, Czech Republic \\ ${ }^{2}$ Department of Management and Informatics, Faculty of Economy, AAB College in Prishtinë, \\ Elez Berisha Street 56, Industrial Zone Prishtinë - Fushë Kosovë, 10000 Prishtinë, Republic of Kosovo \\ ${ }^{*}$ E-mail: haziri@utb.cz
}

\begin{abstract}
Purpose - the purpose of the current research was to investigate the influence of the experience of players and no-players on their purchasing behavior in a gamified purchasing setting.

Research methodology - PLS-SEM has been employed to investigate the effect of gaming on consumer behavior and analyze the data gathered via the questionnaire distributed online.

Findings - unlike studies in different domains, where the positive impact of game experience in a gamified learning environment and purchasing intention towards gamified products has been highlighted, the results of this research reveal the irrelevance of game experience in online purchasing behavior.

Research limitations - firstly, no comparison has been made concerning the differences between board-games and online games. Secondly, the length of time spent playing has not been analyzed. Lastly, the research does not offer any insight regarding the country, nor compare online and offline buying behavior.

Practical implications - eventually, game experience needlessly impacts the purchasing process in a gamified setting. Game design, personality, characteristics, cultural background and other attributes of the participants are an important caveat.

Originality/Value - the research reveals stimulating results for scholars in the field of gamification, game elements, consumer behavior, and online purchasing.
\end{abstract}

Keywords: aesthetics, dynamics, game experience, game mechanics, online buying behavior, social media, developing countries.

JEL Classification: M31.

Conference topic: Digitalization of Business Processes: Trends, Challenges, Solutions.

\section{Introduction}

Selling goods via social platforms has received increasing attention due to the benefits of social media as a new revenue model for companies and as a networking medium which facilitates communication with consumers, ensures quicker responding to consumer inquiries, provides appealing information sharing and consumer attraction techniques, and increases the possibilities for becoming an international company. This description is undeniably true. The majority of social media users consider social media as an influencer towards purchasing decision due to their easy accessibility, time saver function, information abundance, and credibility (Jashari \& Rrustemi, 2017). According to the Kosovo Agency of Statistics reports (Deliu, Haqifi, Morina, Cakolli, \& Sylejmani, 2019; Deliu, Haqifi, Morina, \& Sylejmani, 2018) the number of internet user increased from $82.9 \%$ to $93.2 \%$ during 2018. Moreover, the use of the internet for online purchasing, public services and for processing their inquiries, in general, has increased to $4.4 \%$ compared with the internet use for the same purpose during 2017. Progress is followed in all countries of Eastern Europe; however, Kosovo is at the top with the highest number of internet penetrators (Wilczyński, 2014). This gradual annual rise of internet penetration is naturally prone to receive attention from companies and researchers in the field of marketing.

Games have used a form of relaxing and during leisure time. Based on Limelight Networks report (2018), players spent around six hours weekly playing video games. In addition to entertainment, games can be employed to motivate players towards certain behaviors. While utilitarian games are employed to arouse players with the sense of usefulness, 
hedonic games are played to satisfy the need for pleasant sensations in the player. Additionally, games may be employed to fulfill a dual-purpose through information systems. The suggestion is based on the findings with respect to hedonic games which revealed a positive relationship between factors that impact more than one other factor, such as attitude influence of play intention; enjoyment is influenced by playing intention and attitude; perceived usefulness by perceived ease of use and attitude; enjoyment is connected with perceived usefulness; and ease of use had an impact in perceived usefulness and enjoyment. Conversely, these factors did not have the same effect when it came to utilitarian games. Based on the results, a strong relationship was shown between attitude and playing intention, between usefulness and intention, and between enjoyment and perceived usefulness, followed by the influence of perceived usefulness on attitude, perceived ease of use with enjoyment and perceived usefulness (Hamari \& Keronen, 2017). Hence, scholars introduced game elements as a successful technique for achieving results.

Due to lack of elucidation regarding the game experience impact on online purchasing, this research paper aims to investigate the influence of the experience of players and no-players on their purchasing behavior in a gamified purchasing setting. The contribution of this research is manifold. Initially, it investigates the game experience impact on purchasing decision. Afterward, it explores the influence of game experience on game elements. For research purpose, game elements have been designed based on the MDA (mechanics, dynamics, and aesthetics) Framework (Kim \& Lee, 2015). Furthermore, each construct was investigated based on the structural model in respect of the relationship significance. Previously, researchers have focused on the impact of games on improved performance, motivation, socialization, and behavioral changing (Chou \& Wang, 2016; Hsiao \& Chiou, 2012; Teng \& Chen, 2014). The MDA Framework has been studied in terms of gamification strategy design, implementation, management and optimization of gamification strategy. Management, education, business, music industry, innovation, behavioral change, and health are few of the fields where game elements have been considered (Chang \& Wei, 2016; Lopez \& Tucker, 2017; Robson, Plangger, Kietzmann, McCarthy, \& Pitt, 2015). To the authors' knowledge, this is the first time that the MDA Framework has been applied in combination with the game experience in a study of social media purchasing, supported by data from a Balkan country, the Republic of Kosovo.

The paper is organized as follows. The first sections provide a brief introduction to the topic. It continues with the theoretical background where gamification features, social media, game elements, and its impact were included along with previous research work. The paper then proceeds with the hypothesis presentation, a description of methodology procedures, data collection methodology, results of the study, implications, and limitations requiring further research.

\section{Literature review}

Engaging and motivating costumers seem to be challenging for companies. Moreover, gamification is considered as a technique of motivating and engaging consumers, end-users, students, patients, and participants by employing game elements. Positive behavioral changes when gamification is considered have been noticed in most extreme cases, such as alcohol consumption prevention among college students and depression treatment. Furthermore, Boyle, Earle, LaBrie, and Smith (2017) suggest the employment of gamification as one of the methods of efficient enhancement of alcohol consumption prevention. According to Dias, Barbosa, and Vianna (2017) gamification and use serious games has shown a moderated effect in supporting patients suffering from mid-level depression, while regardless of their beneficial impact on patient treatment, gamification and serious games did not result important in the patients' cure.

Generally, purchasing via social platforms seems to facilitate the purchasing process, which a note of variability, however, when it comes to the factors which influence the purchase decision. Suggestions and collaborative browsing induce a preferable online shopping experience followed with a notably psychological companionship (Wei, Seedorf, Lowry, Thum, \& Schulze, 2017). In addition to the experience, according to Dong and Li (2018) the consumer-toconsumer communication fosters the relationship between them and effects on consumer persuasion. Beside purchasing via social platforms, purchasing virtual items is not mainstream. Subsequently, purchasing game items online appeared to be influenced by psychological factors which later are expected to be evoked throughout game player behavior. Namely, psychological engagement will mirror the player's behavioral engagement status (Cheung, Shen, Lee, \& Chan, 2015). Lopez and Tucker (2017) presented that the game influence in connection to performing a task is positively linked with the physical effort required to complete the task. Additionally, game components such as points and avatar resulted to positively influence performance and negatively impact indirect tasks which are a result of the content unlocking component.

The game industry and games, in general, are not only considered as a means for leisure but also for engagement and motivation towards desirable behavior. The Marxist theory explains computer games as a technology manifestation where players aim to create a better reality according to their preferences (Kirkpatrick, Mazierska, \& Kristensen, 2016) and the factors determining whether to play or not include player's video game habits, the likelihood for addiction and their intentions (Hartmann, Jung, \& Vorderer, 2012). In addition, loyalty to mobile games and price remarkably affects the players' intention to purchase via mobile applications. Playfulness, connectedness, flexibility, and reward positively impact the player loyalty although the impact of such factors on non-players is lower ( Hsiao \& Chen, 2016). 
Applying game elements in a non-game context aim to induce the same feeling and attachment evoked by games in the player. Presumably, the existence of various types of games leads to diverse results, the reasoning of usage and implications. The intention to use is not perceived homogeneously across gamification, serious games, social games, simulation games, and games-for-a-purpose. Players defined the meta-game reward system as a beneficial system due to the evoked set of feelings related to pleasure, self-esteem and social status (Cruz, Hanus, \& Fox, 2017). Due to game elements diversification the frequency of expressions such as game mechanics, game dynamics and aesthetics appeared to be high. Moreover, the successful application of game elements has yielded remarkable results. Likewise, the game mechanics element, reward, improved video game players' task performance and declarative memory tasks. The results suggested that playing games may have an impact on the part of the brain associated with memory, emotions, and motivation (Prena, Reed, Weaver, \& Newman, 2018). Virtual items are purchased when they express the players' uniqueness, exclusivity, function, social appeal, and collectability. Overall, the players' welfare was impacted by the possibility of obtaining virtual items and gaming (Cleghorn \& Griffiths, 2015). Furthermore, Hamari and Lehdonvirta (2010) suggested that game elements which can be used to induce repeated purchase are item degradation, inconvenient gameplay elements, currency as a medium, avatars, special occasions, artificial scarcity and alternatives to existing content. Furthermore, the avatars importance in twofold, due to the fact of an attribute which is strongly linked to determining game-base behavior and market segmentation factors. In addition to repeated purchase, consumers were more likely to be willing to pay more when it came to items for which they obtained points and currency. Oh and Ryu (2007) suggested that items which include game elements and are in bundle package might increase sales. Game challenges, in-game flow, and player personality are aligned with the game experience (Alexiou \& Schippers, 2018). In view of the benefits of game elements usage and aiming to dwindle the gap regarding the impact of game experience on game elements, the following hypotheses have been designed:

Hypothesis 1: Aesthetics are positively affected (H1a) by experienced players who purchased via social platforms at least once and the relationship is significant $(\mathrm{H} 1 \mathrm{~b})$.

Hypothesis 2: Game dynamics are positively influenced $(\mathrm{H} 2 \mathrm{a})$ by the game experience of social media purchasers and the relationship is significant $(\mathrm{H} 2 \mathrm{~b})$.

Hypothesis 3: Game experience positively impacts (H3a) game mechanics for experienced social media purchasers and the relationship is significant $(\mathrm{H} 3 \mathrm{~b})$.

Explaining and defining the obsession created by games in the player appears to be challenging. Also, in view of diverging factors, such obsession varies among players along with the type of game. The positive connection between happiness evoked while playing games, on one hand, and advertising, on the other hand, leads to better advertising outcomes and prompts and motivates players to continue playing and experimenting (Chou \& Wang, 2016). A study by Park and Lee (2011) revealed that loyal players ranked visual authority value and monetary value as the crucial factors towards purchasing game items. Due to their influence on customer spending, motivation factors impacting selling in-game content have received considerable attention. According to Hamari et al. (2017), factors may be labeled into unobstructed play, social interaction, competition, rationale, indulging the children and unlocking content. Comparing the impact of the factors on the amount of money spent on in-game content, it resulted that unobstructed play, social interaction, and economic rationale had a significant effect. Hence, designers should pay close attention to the implementation of artificial limitations, difficulties and social influence due to their impact on spending habits within in-game content. Jimenez, San-Martin, Camarero, and San Jose Cabezudo (2019) emphasized that hedonic, social and mainly addiction are motivator which impacts the purchasing intention of game-related products. Liao, Chung, and Chang (2013) emphasized that playing experience of "World of Warcraft" players affect in brand image, brand trust, and eWOM, however, brand image is considered as a determinant factor towards the intention to recommend the playing experience. Although game experience is not studied, attractive social network gamified setting impacted consumer satisfaction and perception of services quality (Liu, Li, Xu, Kostakos, \& Heikkilä, 2016) and purchase intention of gamified products is prognosticate impacted by attitudes and perceived usefulness (Bittner \& Schipper, 2014). Furthermore, intention to recommend is predictably impacted by the extent of information, interpersonal interaction, and generous identification when purchasing in a gamified settings (Sheu, Chu, \& Wang, 2017). As such, mindful of the impact of game experience in different domains, the following hypothesis has been designed: (H4b).

Hypothesis 4: Purchasing behavior is determined ( $\mathrm{H} 4 \mathrm{a}$ ) by game experience and the relationship is significant

\section{Data collection, procedures and research methodology}

The research methodology is composed of three segments. The first segment was data gathering where a questionnaire was distributed online via social platforms. The questionnaire was composed of three sets of five statements. The main elements for each statement were inspired by the MDA Framework (Kim \& Lee, 2015). Each statement employed a Likert scale (from 1-Totally disagree to 5-Totally agree) to measure the participants' level of agreement. Two closedended questions regarding game experience and purchasing frequency were also included in the questionnaire. The respondents were asked, "Do you play games (video games, computer games, puzzles, any other game)"? and they were also asked to choose "yes" if they played in the past but not that often in the last few weeks. The second question 
was modified from Baptista and Oliveira (2017) and it was formulated as it follows: "I bought via social media:" where they could choose "only once $=0$, twice $=1$, three times $=2$, more than three times $=3$, every season $=4$, every month $=5$, every week $=6$, every day $=7$ ". Furthermore, the questionnaire was distributed in all cities of Kosovo in order to be able to generalize the results. To be part of the sample, participants had to have purchased previously via social platforms at least once. The sampling technique used for this research was the purposive sampling technique. Regarding the demographic distribution of population and the sample design, the authors referred to reports of the Kosovo Agency of Statistics (Deliu et al., 2018; Krasniqi et al., 2018). After data gathering, 255 qualitative questionnaires were used for further analysis. Previously a pilot test with 50 respondents was conducted. The results of the pilot test supported the reliability and validity of the proportions. The data have been analyzed using SmartPLS version 3.0.

In the second segment, the techniques, procedures, methods, and tests were chosen to analyze the gathered data. The deductive procedure has been followed for this research. Initially, articles related to the game experience and game elements from Scopus and Web of Science were collected. Based on the literature review the gap was defined which lead to problem formulation, the study started from the theoretical knowledge at disposal. Afterward, the questionnaire was designed and distributed. The data were analyzed using several statistical tests and it resulted that PLS-SEM is the most appropriate to reach the aim of the research. Numerous scholars have employed PLS-SEM and to examine the game experience influence on loyalty toward online games (N. M. Suki, \& N. M. Suki, 2017), game experience impact on brand trust, brand image and eWOM (Liao et al., 2013), and purchasing intention towards gamified products (Jimenez et al., 2019). The standard procedures described by Vinzi, Chin, Henseler, and Wang (2010) and Hair, Hult, Ringle, and Sarstedt (2017) were considered. The model was first created, followed by the path modeling creation and calculation.

The third segment consisted of designing and creating the model which is explained in details in the following section. The MDA framework was used as inspiration in constructing the model. Afterward, game experience and user behavior were added in order to reach the research aim. Hypotheses and the research, in general, were designed following the model.

\section{Results and discussion}

For this research purposes, PLS-SEM was employed due to its aim which is to evaluate the variance of the internal cause of constructs and their corresponding manifest variables in turn (Vinzi et al., 2010), that subsequently aligns with the goal of this study. Firstly, the structural model was designed to assist the representation of the constructs by defining the variables and their relationship. Secondly, the measurement model of the constructs was calculated in order to demonstrate the relationships between the constructs and indicated variables (Hair et al., 2017).

\subsection{Measurement model}

The summary of the results of the measurement model is shown in Table 2, 3 and 4. Initially, the frequency of two closed-ended questions shows that $51 \%$ of respondents had played and continue to play different games and $49 \%$ did not play games $\left(\mathrm{SD}=.501, \sigma^{2}=.251, \overline{\mathrm{x}}=.49\right)$. Concerning the purchasing frequency, $8.6 \%$ of respondents had purchased only once, followed by $10.6 \%$ who had purchased twice, $10.2 \%$ who had purchased three times, while the majority of the respondents purchased more than three times $(51.8 \%)$, with comparatively less social platforms users who purchased every season (5.5\%), every month (11.8\%) and every week (1.6\%). Regarding the demographic characteristics of participants, they are presented in Table 1.

Table 2 presents the item loading, the Cronbach's alpha coefficients, composite reliability, and average variance extracted. Due to low loading three items of game dynamics and game mechanics have been removed. The Cronbach's alpha $(.93, .74, .68,1.0,1.0)$ are above the minimum requirements of .70 which may be considered as satisfactory. However, for game mechanics, it is .68, which according to Lyberg et al. (1997) is acceptable. Furthermore, the composite reliability of constructs fluctuates from 1.0 to .84, which overreached the minimum criteria of .60. Eventually, the constructs revealed satisfactory convergence reliability. Game mechanics resulted to obtain an average variance extracted (AVE) of .73, game dynamics .76 and for aesthetics is .73, which is higher than the minimum criteria of .7, indicating that AVE value explains more than half of the variance of its indicators, namely demonstrates sufficient convergent validity.

Table 1. Demographic characteristics of participants $(\mathrm{N}=255)$ (source: authors' own work)

\begin{tabular}{|c|c|c|}
\hline Characteristics & $\mathrm{n}$ & $\%$ \\
\hline \multicolumn{3}{|c|}{ Age at the time of the survey } \\
\hline $18-24$ & 77 & 30.2 \\
\hline $25-35$ & 139 & 54.5 \\
\hline $36-50$ & 33 & 12.9 \\
\hline $51-65$ & 6 & 2.4 \\
\hline
\end{tabular}


End of Table 1

\begin{tabular}{|c|c|c|}
\hline Characteristics & $\mathrm{n}$ & $\%$ \\
\hline \multicolumn{3}{|c|}{ Gender } \\
\hline Female & 160 & 62.7 \\
\hline Male & 95 & 37.3 \\
\hline \multicolumn{3}{|c|}{ District } \\
\hline Prishtinë & 72 & 28.2 \\
\hline Mitrovicë & 14 & 5.5 \\
\hline Pejë & 27 & 10.6 \\
\hline Prizren & 17 & 6.7 \\
\hline Ferizaj & 76 & 29.8 \\
\hline Gjilan & 37 & 14.5 \\
\hline Gjakovë & 12 & 4.7 \\
\hline \multicolumn{3}{|c|}{ Employment status } \\
\hline Employed & 162 & 63.5 \\
\hline Unemployed & 93 & 36.5 \\
\hline \multicolumn{3}{|c|}{ Education } \\
\hline High school & 12 & 4.7 \\
\hline Bachelor & 127 & 49.8 \\
\hline Master & 107 & 42 \\
\hline More than master & 9 & 3.5 \\
\hline
\end{tabular}

Table 2. Summary of constructs reliability and validity results (source: authors' own work)

\begin{tabular}{|c|c|c|c|c|}
\hline Constructs & Loading & Cronbach's Alpha & Composite Reliability & AVE \\
\hline \multirow{2}{*}{ Game mechanics } & .74 & \multirow{2}{*}{.68} & \multirow{2}{*}{.94} & \multirow{2}{*}{.77} \\
\hline & .95 & & & \\
\hline \multirow[t]{2}{*}{ Game dynamics } & .75 & \multirow{2}{*}{.74} & \multirow{2}{*}{.86} & \multirow{2}{*}{.76} \\
\hline & .97 & & & \\
\hline \multirow[t]{5}{*}{ Aesthetics } & .87 & \multirow{5}{*}{.93} & \multirow{5}{*}{.84} & \multirow{5}{*}{.73} \\
\hline & .88 & & & \\
\hline & .85 & & & \\
\hline & .91 & & & \\
\hline & .87 & & & \\
\hline Game experience & 1.0 & 1.0 & 1.0 & 1.0 \\
\hline User behavior & 1.0 & 1.0 & 1.0 & 1.0 \\
\hline
\end{tabular}

Table 3. Cross-loadings of measurement items summarized (source: authors' own work)

\begin{tabular}{|l|c|c|c|c|c|c|}
\hline \multicolumn{1}{|c|}{ Dimension } & Items & Aesthetics & Game dynamics & Game mechanics & Game experience & User behavior \\
\hline Aesthetics & AS01 & $\mathbf{0 . 8 7 1}$ & 0.496 & 0.426 & -0.089 & 0.076 \\
\cline { 2 - 7 } & AS02 & $\mathbf{0 . 8 8 6}$ & 0.565 & 0.524 & -0.048 & 0.102 \\
\cline { 2 - 7 } & AS03 & $\mathbf{0 . 8 5 8}$ & 0.594 & 0.506 & -0.024 & 0.161 \\
\cline { 2 - 7 } & AS04 & $\mathbf{0 . 9 1 4}$ & 0.588 & 0.486 & -0.055 & 0.219 \\
\cline { 2 - 7 } & AS05 & $\mathbf{0 . 8 7 8}$ & 0.520 & 0.502 & -0.071 & 0.169 \\
\hline Game dynamics & DY04 & 0.703 & $\mathbf{0 . 7 5 8}$ & 0.515 & -0.065 & 0.159 \\
\cline { 2 - 7 } & DY05 & 0.517 & $\mathbf{0 . 9 7 6}$ & 0.420 & -0.195 & 0.100 \\
\hline Game mechanics & GM01 & 0.502 & 0.342 & $\mathbf{0 . 7 4 9}$ & -0.048 & 0.044 \\
\cline { 2 - 7 } & GM02 & 0.478 & 0.469 & $\mathbf{0 . 9 5 7}$ & -0.109 & 0.094 \\
\hline Game experience & FQ05 & .07 & -0.176 & -0.101 & $\mathbf{1 . 0 0 0}$ & -0.054 \\
\hline User behavior & UB01 & .15 & 0.124 & 0.088 & -0.054 & $\mathbf{1 . 0 0 0}$ \\
\hline
\end{tabular}


The cross-loading of measurement items is summarized in Table 3. It is notable in the summary that the items are ranked between 0.74 to 1.00 which satisfies and overreaches the minimum criteria of 0.6 . Table 4 presents the output of discriminant validity based on Fornell-Larcker Criterion. According to Fornell and Larcker (1981) investigation if AVE square root transcends the constructs intern-correlation constructs have discriminant validity. Therefore, the results are shown in Table 2 and 3 indicate that the criteria are fulfilled and constructs have discriminant validity.

Table 4. Summary of discriminant validity (source: authors' own work)

\begin{tabular}{|l|c|c|c|c|c|}
\hline \multicolumn{1}{|c|}{ Constructs } & AS & DY & GM & GE & UB \\
\hline Game mechanics & 0.882 & & & & \\
\hline Game dynamics & 0.611 & 0.874 & & & \\
\hline Aesthetics & 0.543 & 0.482 & 0.859 & & \\
\hline Game experience & -0.074 & -0.176 & -0.101 & 1.000 & \\
\hline User behavior & 0.156 & 0.124 & 0.088 & -0.054 & 1.000 \\
\hline
\end{tabular}

\subsection{Structural model}

The results of the measurement model confirmed the reliability and validity of the data, hence allowing to continue with the structural model and hypotheses relationship investigation. The evaluation of the structural model is depicted in Table 5. However, the model constructs for hypothesis testing has been displayed in Figure 1. Regarding the impact of game experience in user behavior and game elements resulted to be negative for all paths. Namely, negative values mirror the negative relationship. Additionally, the significance level was 0.05 and the test type was two-tailed.

Aesthetics are negatively affected $(\beta=-0.08)$ by experienced players who purchased via social platforms at least once and the relationship is insignificant $(p=0.41)$, thus rejecting H1a and H1b. Game dynamics are negatively influenced $(\beta=-0.18)$ by the game experience of social media purchasers and the relationship is significant $(p=0.002)$ leading to rejecting $\mathrm{H} 2 \mathrm{a}$ but supporting $\mathrm{H} 2 \mathrm{~b}$. Another game element negatively impacted $(\beta=-0.11)$ with game experience is game mechanics for experienced social media purchasers and the relationship is insignificant $(p=0.15)$, so $\mathrm{H} 3 \mathrm{a}$ and $\mathrm{H} 3 \mathrm{~b}$ are not supported. The results contradict the previous work where game experience had an impact on purchase repetition (Hamari \& Lehdonvirta, 2010; Oh \& Ryu, 2007). Lastly, no differences were identified in terms of game mechanics for Kosovars consumers who purchased via social media when age and city were employed as moderators (Haziri \& Chovancova, 2018).

Table 5. Structural model evaluation (source: authors' own work)

\begin{tabular}{|c|c|c|c|c|c|}
\hline Constructs & Path & Standardized Estimate & t-value & $\mathrm{R}^{2}$ & $\mathrm{p}$-value \\
\hline AS & Game experience $->$ Aesthetics & -0.08 & .82 & .59 & .41 \\
\hline DY & Game experience $->$ Game dynamics & -0.18 & .16 & .10 & .002 \\
\hline GM & Game experience $->$ Game mechanics & -0.11 & .43 & .44 & .15 \\
\hline UB & Game experience $->$ User behavior & -0.05 & .86 & .73 & .39 \\
\hline
\end{tabular}

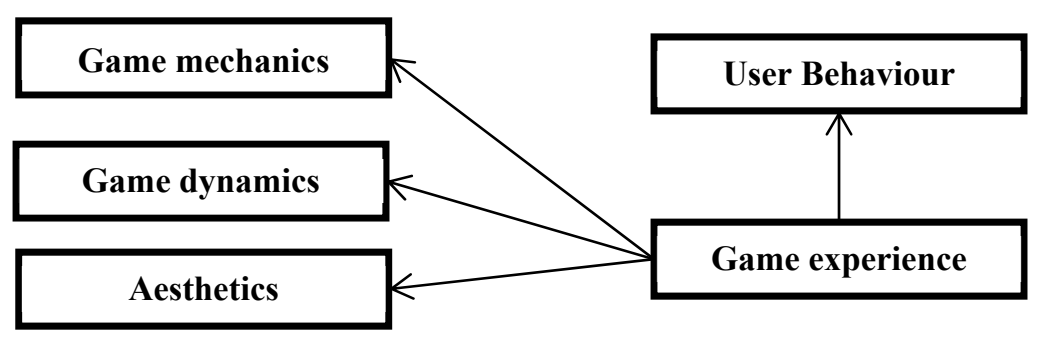

Figure 1. The model constructs for hypothesis testing (source: authors' own work)

Purchasing behavior is not determined $(\beta=-0.05)$ by game experience and the relationship is insignificant $(p=$ 0.39), meaning that $\mathrm{H} 4 \mathrm{a}$ and $\mathrm{H} 4 \mathrm{~b}$ are not supported. The results are in the same line with the previous research conducted by Dardis et al. (2015) where game-playing experience unanticipated the prediction of behavior changes towards purchasing intention. On the other hand, the results contradict the research work where game experienced American learners performed better (Landers \& Armstrong, 2017) and game experienced Belgians and Hollander's 
consumers retained greater purchase intention towards gamified products (Bittner \& Schipper, 2014). Also, Ravoniarison and Benito (2019) concluded that progressing within the game stimulate the willingness to upgrade in-app purchasing, hence, the game success is expected to impact the in-app purchasing decision.

The interpretation of $\mathrm{R}^{2}$ provides information regarding the power of the structural model within the final dependent construct. According to results presented in Table 4, aesthetics (59\%), user behavior (73\%) and game mechanics $(44 \%)$ had a high share of variance. Hence, the constructs had a satisfactory level of predicting the power of the modeled construct of game experience impact on game elements and user behavior.

The authors aimed to investigate the impact of game experience on purchasing behavior and game elements. Although the results contradict the research work conducted previously, the gamification may not reach players' expectation similar to $80 \%$ of cases failure due to poor design (Thiebes, Lins, \& Basten, 2014) and careless management (Insley \& Nunan, 2014). The appropriated design and appliance of game elements resulted to be crucial. Followed with personality, characteristics, cultural background and other attributes of participants or members in the gamified environment, the mentioned factors resulted to be important in such setting and adjusting them may to be the direct path to success. Also, player experience and player personality were imbalanced and it resulted in futile when designing and predicting preferences for game mechanics (Ferro, 2018). The gamified environment tends to influence user experience by utilitarian and hedonic features. Such influence is expected to reflect in perceived benefits, types of perceived value, and brand equity (Hsu \& Chen, 2018) whereas in developing countries price is an extraordinarily important factor when purchasing (Hawary \& Harahsheh, 2014). Hence, consumers in developing countries are sensitive to the prices rather than brand equity. Furthermore, according to a World Bank report (2018a), Kosovo as a post-conflict state is grouped under developing group due to its low GDP growth (the annual GDP growth was 3.7\% in 2017) and low GDP per capita (less than USD 5). As reported by the World Bank (2018b) the unemployment rate in Kosovo during 2016 was $27.47 \%$ where the average age is 30.2 years old (Krasniqi et al., 2018). Evidently, Kosovar consumers are unaffected by game experience when purchasing in a gamified setting via social platforms, demographic and cultural differences might be the cause of the obtained differences.

\section{Conclusions}

Game elements provide useful information regarding the behavioural change in respect of motivation and engagement. Due to players' arousal with commitment, joy and delight while playing, scholars, companies, teachers, professors, trainers and numerous different domains are exploring game elements to evoke those feelings in the consumers, students, participants, and end-users. Considering that social platforms are used by numberless users for shopping items or booking vacations, it is worthwhile to investigate consumer engagement and motivation towards purchasing decision and purchasing intention. Following the mentioned trends, the results of this study revealed that game experience impacts negatively game elements and purchasing behavior of social platforms users. Additionally, the relationship between game experience and game dynamics resulted statistically significant despite the statistical insignificance relationship between game experience and game mechanics, aesthetics and user behavior.

This study built on the MDA Framework was conducted to examine the impact of game experience on purchasing behavior and game elements. Based on the literature review the theoretical and practical gap was identified, which lead to model construct, research, and methodology design. A questionnaire was designed by using the MDA framework elements which are game mechanics, game dynamics and aesthetics. Before distribution, the questionnaire was tested with a small sample and after testing the reliability and validity of the data, it was distributed across all cities in Kosovo. The gathered data were analyzed using SmartPLS version 3.0 software due to its benefits and consentaneity with the research aim. The model was designed based on the literature review, the data analysis methods and statistical test were selected in concordance with the model.

The findings of this research may be used as a foundation for further study into the consumer behavior domain when game elements and game experience are considered. The present study contributed to and advanced the theoretical and practical understanding of the gamification and the impact of game experience on game elements and online purchasing behavior in developing countries. Additionally, by investigating the game experience impact this study also contributed to improving the understanding of game elements and their relationship with game experience. The authors aim to dwindle the gap by providing information regarding the game experience influence on purchasing via social platforms in a gamified setting for consumers in developing countries, respectively Kosovar consumers. The study provides important insights into the influence of game experience which is related to game elements usage in a nongame context and into the relationship significance between constructs in the model. Briefly, the research reveals stimulating results for scholars in the field of gamification, game elements, consumer behavior, and online purchasing. The contribution lies in the dissimilarity of results presented in this research work. To the authors' knowledge, the present study is one of the first in the area of consumer behavior employing gamified content and mathematical methods, including PLS-SEM to online shopping behavior.

Eventually, the study has several limitations that invite researchers for further examination and investigation. With regards to the sample used in this research, it can be concluded that it is biased due to the fact that only social platforms users who had purchased via social media were part of this study. The respondents were only Albanian 
speakers from Kosovo, hence it would be inadvisable to generalize the data for all Balkan countries or developing countries. Although the findings of this research can be generalized to countries who share the same similarities with Kosovo in terms of regional, economical, institutional, political and terminological advancement with developing countries, the findings of this research are limited to only one country. Also, the comparison of online and offline purchasing behavior within Kosovars consumers nor other countries has not been conducted. Thus, further research could be carried out in other countries and the results are subjected to comparison. Additional moderators could be added and the research conducted with different cultures, settings, and individuals. Furthermore, different game elements could be employed and the model construct is modified. The present study did not investigate the relationship of game type and game elements nor the length of time spent playing which allow researchers to further explore in this direction. As mentioned by Ferro (2018), the player personality to predict purchasing behavior could also be a fruitful direction for future research. Not every consumer is motivated by the same technique or factors to purchase nor players are motivated in the same manner, so a comparison between playing motivational factors and purchasing motivational factors in a gamified environment may provide interesting results. Lastly, for researchers, this study can be used as a basis for further refinement of individuals and for further research regarding gamification and online buying behavior. For practitioners, understanding the basic constructs is essential to design and implement game elements to boost consumer purchasing experience with joy and delight with the correct application of game technique. Eventually, game experience needlessly impacts the purchasing process in a gamified setting. Game design, personality, characteristics, cultural background and other attributes of the participants are an important caveat.

\section{Funding}

The authors are thankful for the financial support provided by the Internal Grant Agency of Tomas Bata University in Zlin, no. IGA/FaME/2018/2020: Consumer behavior changes and entrepreneurship for market development through digitization.

\section{Disclosure statement}

The authors do not have any competing financial, professional, or personal interests from other parties.

\section{References}

Alexiou, A., \& Schippers, M. C. (2018). Digital game elements, user experience and learning: A conceptual framework. Education and Information Technologies, 23(6), 2545-2567. https://doi.org/10.1007/s10639-018-9730-6

Baptista, G., \& Oliveira, T. (2017). Why so serious? Gamification impact in the acceptance of mobile banking services. Internet Research, 27(1), 118-139. https://doi.org/10.1108/IntR-10-2015-0295

Bittner, J. V., \& Schipper, J. (2014). Motivational effects and age differences of gamification in product advertising. Journal of Consumer Marketing, 31(5), 391-400. https://doi.org/10.1108/JCM-04-2014-0945

Boyle, S. C., Earle, A. M., LaBrie, J. W., \& Smith, D. J. (2017). PNF 2.0? Initial evidence that gamification can increase the efficacy of brief, web-based personalized normative feedback alcohol interventions. Addictive Behaviors, 67, 8-17. https://doi.org/10.1016/j.addbeh.2016.11.024

Chang, J. W., \& Wei, H.-Y. (2016). Exploring engaging gamification mechanics in massive online open courses. Educational Technology \& Society, 19(2), 177-203. Retrieved from https://search.proquest.com/docview/1792129422?accountid=15518

Cheung, C. M. K., Shen, X.-L., Lee, Z. W. Y., \& Chan, T. K. H. (2015). Promoting sales of online games through customer engagement. Electronic Commerce Research and Applications, 14(4), 241-250. https://doi.org/10.1016/j.elerap.2015.03.001

Chou, H.-Y., \& Wang, S. S. (2016). The effects of happiness types and happiness congruity on game app advertising and environments. Electronic Commerce Research and Applications, 20, 1-14. https://doi.org/10.1016/J.ELERAP.2016.09.001

Cleghorn, J., \& Griffiths, M. D. (2015). Why do gamers buy "Virtual Assets"? Digital Education Review, (27), 85-104. Retrieved from https://dialnet.unirioja.es/servlet/articulo?codigo=5495907

Cruz, C., Hanus, M. D., \& Fox, J. (2017). The need to achieve: Players' perceptions and uses of extrinsic meta-game reward systems for video game consoles. Computers in Human Behavior, 71, 516-524. https://doi.org/10.1016/j.chb.2015.08.017

Dardis, F. E., Schmierbach, M., Ahern, L., Fraustino, J., Bellur, S., Brooks, S., \& Johnson, J. (2015). Effects of In-Game Virtual Direct Experience (VDE) on reactions to real-world brands. Journal of Promotion Management, 21(3), 313-334. https://doi.org/10.1080/10496491.2015.1021503

Deliu, E., Haqifi, B., Morina, H., Cakolli, A., \& Sylejmani, D. (2019). Rezultatet e Anketës së Përdorimit të Teknologjisë Informative dhe Komunikimit 2018. English: The results of informative and communication technology usage survey 2018. Prishtinë. Republic of Kosovo: Kosovo Agency of Statistics. Retrieved from http://ask.rks-gov.net/media/4544/tik-2018.pdf

Deliu, E., Haqifi, B., Morina, H., \& Sylejmani, D. (2018). Rezultatet e Anketës së Përdorimit të Teknologjisë Informative dhe Komunikimit 2017. English: The results of informative and communication technology usage survey 2017. Prishtinë. Republic of Kosovo: Kosovo Agency of Statistics. Retrieved from http://ask.rks-gov.net/media/3828/tik-2017.pdf

Dias, L. P. S., Barbosa, J. L. V., \& Vianna, H. D. (2017). Gamification and serious games in depression care: A systematic mapping study. Telematics and Informatics, 35, 213-224. https://doi.org/10.1016/j.tele.2017.11.002 
Dong, X., \& Li, H. (2018). Does online media sequence matter in product marketing? Electronic Commerce Research and Applications, 28, 44-53. https://doi.org/10.1016/J.ELERAP.2018.01.010

Ferro, L. S. (2018). An analysis of players' personality type and preferences for game elements and mechanics. Entertainment Computing, 27, 73-81. https://doi.org/10.1016/J.ENTCOM.2018.03.003

Fornell, C., \& Larcker, D. F. (1981). Evaluating structural equation models with unobservable variables and measurement error. Journal of Marketing Research, 18(1), 39-50. https://doi.org/10.1177/002224378101800104

Hair, J. J. F., Hult, G. T. M., Ringle, C. M., \& Sarstedt, M. (2017). A primer on partial least squares structural equation modeling (2nd ed.). Los Angelos: Sage.

Hamari, J., Alha, K., Järvelä, S., Kivikangas, J. M., Koivisto, J., \& Paavilainen, J. (2017). Why do players buy in-game content? An empirical study on concrete purchase motivations. Computers in Human Behavior, 68, 538-546. https://doi.org/10.1016/j.chb.2016.11.045

Hamari, J., \& Keronen, L. (2017). Why do people play games? A meta-analysis. International Journal of Information Management, 37(3), 125-141. https://doi.org/10.1016/J.IJINFOMGT.2017.01.006

Hamari, J., \& Lehdonvirta, V. (2010). Game design as marketing: How game mechanics create demand for virtual goods. Journal of Business Science and Applied Management, 5(1), 14-29. Retrieved from http://citeseerx.ist.psu.edu/viewdoc/download?doi=10.1.1.306.3478\&rep=rep1\&type=pdf

Hartmann, T., Jung, Y., \& Vorderer, P. (2012). What determines video game use? The impact of users' habits, addictive tendencies, and intentions to play. Journal of Media Psychology, 24(1), 19-30. https://doi.org/10.1027/1864-1105/a000059

Hawary, S. I. S. Al, \& Harahsheh, S. A. M. (2014). Factors affecting Jordanian consumer loyalty toward cellular phone brand. International Journal of Economics and Business Research, 7(3), 349. https://doi.org/10.1504/IJEBR.2014.060372

Haziri, F., \& Chovancova, M. (2018). Game mechanics differences for Kosovars social media purchasers. In K. H. Rozana Veselica, \& Gordana Dukic (Ed.), Economic and Social Development - 36th International Scientific Conference on Economic and Social Development - "Building Resilient Society" (pp. 141-149). Zagreb: Varazdin Development and Entrepreneurship Agency. Retrieved from http://www.esd-conference.com

Hsiao, C. C., \& Chiou, J. S. (2012). The effects of a player's network centrality on resource accessibility, game enjoyment, and continuance intention: A study on online gaming communities. Electronic Commerce Research and Applications, 11(1), 7584. https://doi.org/10.1016/J.ELERAP.2011.10.001

Hsiao, K. L., \& Chen, C. C. (2016). What drives in-app purchase intention for mobile games? An examination of perceived values and loyalty. Electronic Commerce Research and Applications, 16, 18-29. https://doi.org/10.1016/J.ELERAP.2016.01.001

Hsu, C.-L., \& Chen, M.-C. (2018). How does gamification improve user experience? An empirical investigation on the antecedences and consequences of user experience and its mediating role. Technological Forecasting and Social Change, 132, 118-129. https://doi.org/10.1016/j.techfore.2018.01.023

Insley, V., \& Nunan, D. (2014). Gamification and the online retail experience. International Journal of Retail \& Distribution Management, 42(5), 340-351. https://doi.org/10.1108/IJRDM-01-2013-0030

Jashari, F., \& Rrustemi, V. (2017). The impact of social media on consumer behavior-Case study Kosovo. Journal of Knowledge Management, Economics and Information Technology, VII(1), 1-21. Retrieved from www.scientificpapers.org

Jimenez, N., San-Martin, S., Camarero, C., \& San Jose Cabezudo, R. (2019). What kind of video gamer are you? Journal of Consumer Marketing, 36(1), 218-227. https://doi.org/10.1108/JCM-06-2017-2249

Kim, J. T., \& Lee, W.-H. (2015). Dynamical model for gamification of learning (DMGL). Multimedia Tools and Applications, 74(19), 8483-8493. https://doi.org/10.1007/s11042-013-1612-8

Kirkpatrick, G., Mazierska, E., \& Kristensen, L. (2016). Marxism and the computer game. Journal of Gaming \& Virtual Worlds, 8(2), 117-130. https://doi.org/10.1386/jgvw.8.2.117_1

Krasniqi, I., Ulaj, R., Berisha, I. T., Qevani, B., Kastrati, A., Rrustemi, I., ... \& Morina, A. S. (2018). Vjetari Statistikor i Republikës së Kosovës 2018. English: Republic of Kosovo statistical yearbook 2018. Prishtinë. Republic of Kosovo: Kosovo Agency of Statistics. Retrieved from http://ask.rks-gov.net/media/4284/vjetari-statistikor-2018-final.pdf

Landers, R. N., \& Armstrong, M. B. (2017). Enhancing instructional outcomes with gamification: An empirical test of the technology-enhanced training effectiveness model. Computers in Human Behavior, 71, 499-507. https://doi.org/10.1016/J.CHB.2015.07.031

Liao, S. H., Chung, Y. C., \& Chang, W. J. (2013). What can influence the consumers' online word-of-mouth? An online gaming perspective. International Journal of Services Technology and Management, 19(4-6), 278-293. https://doi.org/10.1504/IJSTM.2013.055624

Limelight Networks. (2018). The state of online gaming 2018. Retrieved from https://img03.en25.com/Web/LLNW/\%7B6be6d024012c-4d8b-b230-9c0c9c98e597\%7D_SOOG.pdf

Liu, Y., Li, H., Xu, X., Kostakos, V., \& Heikkilä, J. (2016). Modeling consumer switching behavior in social network games by exploring consumer cognitive dissonance and change experience. Industrial Management \& Data Systems, 116(4), 801-820. https://doi.org/10.1108/IMDS-05-2015-0170

Lopez, C. E., \& Tucker, C. S. (2017). A quantitative method for evaluating the complexity of implementing and performing game features in physically-interactive gamified applications. Computers in Human Behavior, 71, 42-58. https://doi.org/10.1016/J.CHB.2017.01.036

Lyberg, L., Biemer, P., Collins, M., De Leeuw, E., Dippo, C., Schwarz, N., \& Trewin, D. (Eds.). (1997). Survey measurement and process quality. John Wiley \& Sons, Inc. Retrieved from https://books.google.cz/books/about/Survey_measurement_and_process_quality.html?id=my22AAAAIAAJ\&redir_esc=y 
Oh, G., \& Ryu, T. (2007). Game design on item-selling based payment model in Korean online games. In DiGRA 2007 Conference: Situated play (pp. 650-657). Tokyo, Japan. Retrieved from http://homes.lmc.gatech.edu/ cpearce3/DiGRA07/Proceedings/085.pdf

Park, B.-W., \& Lee, K. C. (2011). An empirical analysis of online gamers' perceptions of game items: modified theory of consumption values approach. Cyberpsychology, Behavior, and Social Networking, 14(7-8), 453-459. https://doi.org/10.1089/cyber.2010.0253

Prena, K., Reed, A., Weaver, A. J., \& Newman, S. D. (2018). Game mechanics matter: differences in video game conditions influence memory performance. Communication Research Reports, 35(3), 222-231. https://doi.org/10.1080/08824096.2018.1428545

Ravoniarison, A., \& Benito, C. (2019). Mobile games: players' experiences with in-app purchases. Journal of Research in Interactive Marketing, JRIM-06-2016-0060. https://doi.org/10.1108/JRIM-06-2016-0060

Robson, K., Plangger, K., Kietzmann, J. H., McCarthy, I., \& Pitt, L. (2015). Is it all a game? Understanding the principles of gamification. Business Horizons, 58(4), 411-420. https://doi.org/10.1016/J.BUSHOR.2015.03.006

Sheu, J.-J., Chu, K.-T., \& Wang, S.-M. (2017). The associate impact of individual internal experiences and reference groups on buying behavior: A case study of animations, comics, and games consumers. Telematics and Informatics, 34, $314-325$. https://doi.org/10.1016/j.tele.2016.08.013

Suki, N. M., \& Suki, N. M. (2017). Moderating effects on consumers' loyalty toward online games: a partial least squares approach. Advanced Science Letters, 23(8), 7331-7334. https://doi.org/10.1166/asl.2017.9467

Teng, C.-I., \& Chen, W.-W. (2014). Team participation and online gamer loyalty. Electronic Commerce Research and Applications, 13(1), 24-31. https://doi.org/10.1016/J.ELERAP.2013.08.001

Thiebes, S., Lins, S., \& Basten, D. (2014). Gamifying information systems-a synthesis of gamification mechanics and dynamics. In Twenty Second European Conference on Information Systems, Tel Aviv 2014 (pp. 1-17). Tel Aviv: The European Conferences of Information Systems. Retrieved from https://pdfs.semanticscholar.org/7b5d/41781a96d46acf34127258780299cafe3c66.pdf

Vinzi, V. E., Chin, W. W., Henseler, J., \& Wang, H. (2010). Handbook of partial least squares: concepts, methods and applications. In V. E. Vinzi, W. W. Chin, J. Henseler, \& H. Wang (Eds.). Berlin: Springer Science \& Business Media. https://doi.org/10.1007/978-3-540-32827-8_29

Wei, J., Seedorf, S., Lowry, P. B., Thum, C., \& Schulze, T. (2017). How increased social presence through co-browsing influences user engagement in collaborative online shopping. Electronic Commerce Research and Applications, 24, 84-99. https://doi.org/10.1016/J.ELERAP.2017.07.002

Wilczyński, G. (2014). Demographic report: Facebook users in Europe. Retrieved from https://www.catvertiser.com/blog/demographic-report-facebook-users-in-europe/

World Bank. (2018a). Kosovo - selected indicators. Prishtinë. Retrieved from http://pubdocs.worldbank.org/en/716851492021926391/data-xkx.pdf

World Bank. (2018b). Unemployment. Retrieved from https://data.worldbank.org/indicator/SL.UEM.TOTL.NE.ZS?locations=XK 